\title{
DOI: 10.22620/agrisci.2021.29.011 \\ EFFECTIVENESS OF SYSTEMS OF HERBICIDES IN MAIZE CULTIVATED AT CONDITIONS OF TIPICAL CHERNOZEM
}

\author{
Sonya Goranovska \\ Maize Research Institute - Knezha \\ E-mail: sonq_hristova@mail.bg
}

\begin{abstract}
In 2017 and 2018 is displayed on at temp by block method with 9 herbicides in the experimental field of the Institute of maize in Knezha. The study is performed with a maize hybrid Knezha 613 - group 500-600 by FAO, cultivated without irrigation. Five systems of herbicides were studied, which includes five soil preparations: Adengo 465SC (isoxaflutole + tiencarbazon-metil) at a dose $35 \mathrm{ml} / \mathrm{da}$; Merlin Flex 480SC (isoxaflutole) at a dose $42 \mathrm{ml} / \mathrm{da}$; Spectrum (dimetenamid-P) at a dose $140 \mathrm{ml} / \mathrm{da}$; Gardoprim plus gold (S-metolachlor + terbutilazin) at a dose $450 \mathrm{ml} / \mathrm{da}$ and Dual gold 960EK (S-metolaclor) at a dose $150 \mathrm{ml} / \mathrm{da}$. The study includes also 4 foliar preparations, applied in a phase fourth-fifths leaf of the crop, after the soil products: Elumis (nicosulfuron + mezotrion) at a dose $200 \mathrm{ml} / \mathrm{da}$; Aminopielic 600SL (2,4-D) at a dose $120 \mathrm{ml} / \mathrm{da}$; Lumax (S-metolachlor + terbutilazin + mezotrion) at a dose $300 \mathrm{ml} / \mathrm{da}$; Maton 600EK (2,4-D-ester) at a dose $110 \mathrm{ml} / \mathrm{da}$. Of the tested systems of herbicides with highest efficacy is the system of Dual gold 960EK + Elumis, which reduced the sensitive weeds with $96,6 \%$.
\end{abstract}

Keywords: maize, weeds, herbicides, efficacy, yield

\section{INTRODUCTION}

In the conditions of climate and economic changes, leading to negative consequences for the solution of the food problems of mankind, intensive crops occupy a leading place. In this respect, maize is a crucial crop for the global fodder production. The main problem in growing the crop is the control of weeds. The type of weeds and population density have a negative impact on the growth and productivity of maize, such as plant height, leaf area, grain length and weight, number of grains per row and overall yield reduction. A number of studies have found that worldwide weed losses in maize crops are higher than those caused by insects and diseases combined (Spitters et al., 1989).

A significant number of weeds with the same number of plants per unit area consume 2-3 times more water, several times more nitrogen, phosphorus and potassium than maize. This sharply worsens its development conditions, especially during drought. Weeds, above all high-growing species, such as jonson grass, wild radish, field mustard, pig, etc., also affect the light regime of the crop. Particularly dangerous in this regard is the early weeding of the crops, which in most cases leads to etiolation of plants, weakening of stem strength and reduced photosynthetic activity (Changsaluc et al., 2007).

The reduction of yields and the deterioration of plant production as a result of weeding are directly related to the degree of weeding, weed species, the economic threshold of harmfulness and environmental conditions (Tollenaar et al., 1997).

The requirements of modern agriculture are related to reducing the harmful effects of weeds, as the leading method remains the chemical control. Compared to the mechanical methods of weed control, the chemical control has a number of advantages. With it, the manual labor is reduced to a minimum, as it is usually done mechanically. In trench crops this reduction reaches $50-60 \%$.

A number of authors study the biological effect of soil and foliar herbicides on weeding in maize and grain yields obtained 
from it (Bagrintseva et al., 2011; Malakanova et al., 2013; Kalinova et al., 2014; Golubinova and Marinov-Serafimov, 2019).

The use of herbicides in maize is closely related to the specific soil and climatic conditions of its cultivation (Tonev and Mitkov, 2015; Maric, 2007; Jovovic et al., 2011).

In this sense, it is necessary to expand the studies related to the application of herbicides in the maize grown in a changing climate in different soil types. The chemical control of weeds in maize can be carried out with a large number of registered in our country soil herbicides based on metolachlor, pendimethalin, dimethenamid, isoxaflutol, flumioxazine and others.

Against annual and perennial deciduous weeds in practice are widely used herbicides with active substances 2,4-D, dicamba, mesotrione, prosulfuron and others.

A number of vegetation herbicides based on foramsulfuron, nicosulfuron, rimsulfuron and others have been registered against annual wheat weeds - chicken millet, blood millet, periwinkle species, as well as against jonson grass from seeds and rhizomes.

The large number of soil and vegetation herbicides registered in maize allow for effective weed control and higher yields. The obtained results will be used as a basis for the creation of appropriate strategies for weed control, including systems of agrotechnical and plant protection products.

\section{MATERIALS AND METHODS}

To clarify the goal in 2017 and 2018, an experiment was conducted in the field of the Maize Research Institute - Knezha. The studies were performed with Kneja-613 hybrid - group 500-600 according to FAO, grown under non-irrigated conditions, after wheat predecessor.

The experiments are for betting by the block method, in 4 repetitions with the size of the experimental plot $29.4 \mathrm{~m} 2$. The experiment includes 5 variants with herbicides and two controls.
1. Adengo 465SK (isocaflutol + tiencarbazon-methyl) in a dose of $35 \mathrm{ml} / \mathrm{dka}+$ Elumis - $200 \mathrm{ml} / \mathrm{dka}$

2. Merlin flex $480 \mathrm{CK}$ (isoxaflutol) in a dose of $42 \mathrm{ml} / \mathrm{dka}+$ Aminopielik 600CЛ (2,4D-amine salt) in a dose of $120 \mathrm{ml} / \mathrm{dka}$

3. Spectrum (dimethenamid-P) in a dose of $150 \mathrm{ml} / \mathrm{dca}+$ Lumax (S-metolachlor + terbuthylazine + mesotrione) in a dose of 300 $\mathrm{ml} / \mathrm{dca}$

4. Gardoprim plus gold (S-metolachlor + terbuthylazine) in a dose of $450 \mathrm{ml} / \mathrm{dka}+$ Maton 600EK (2,4-D-ester) in a dose of 110 $\mathrm{ml} / \mathrm{dka}$

5. Dual Gold 960EK (S-metolachlor) in a dose of $150 \mathrm{ml} / \mathrm{dca}+$ Elumis (nicosulfuron + mesotrione) in a dose of $200 \mathrm{ml} / \mathrm{dca}$

6. Control - zero (without hoeing and without herbicides)

7. Control - economic (with 2 hoeing, without herbicides)

Weeds were counted quantitatively, by counting by species using $0.25 \mathrm{~m} 2$ meters in 4 replications (Dimitrova, M. et. Al., 2004).

The efficacy of the herbicide systems was reported on the 20th and 40th day after treatment. The percentage of weeds destroyed was calculated on the basis of economic control.

\section{RESULTS AND DISCUSSION}

The results of the study on the species composition of weeds in the experimental field of the Maize Research Institute on nonirrigated areas with corn hybrid Kneja-613 group 600 by FAO show that in the period 2017-2018 the most common weeds are: white dog quinoa (Chenopodium album L.); spread out (Amaranthus blitoides L.); common aster (Amaranthus retroflexus L.); field mustard (Sinapis arvensis L.); purslane (Portutaca oleracea L.); black dog grapes (Solanum nigrum L.); green periwinkle (Setaria viridis (L.) P. Beanv); bonito (Cirsium arvense L. Scop.) and Jonson grass (Sorghum halepense (L.) Pers.).

The system of the soil herbicide Adengo 465SK and the leaf Elumis in the first 
year of the study killed $93.2 \%$ of the total number of weeds, and in the second $-87.5 \%$ in the first report 20 days after treatment with the leaf preparation. A large part of the annual deciduous weeds and part of the cereal weed species, including jonson grass, have been destroyed. This is due to the action of the foliar herbicide Elumis, which has a broad spectrum of action and can be used for double treatment with a high degree of weeding.

The herbicide system of soil preparation Merlin flex $480 \mathrm{CK}$, applied in a dose of $42 \mathrm{ml} / \mathrm{dka}$ and the leaf Aminopielik 600C $Л$ in a dose of $120 \mathrm{ml} / \mathrm{dka}$ in 2017 has $71.8 \%$ efficiency, and in $2018-73.4 \%$. The total number of unaffected weed species is 25 / $\mathrm{m} 2$, and in the zero control is $88.5 / \mathrm{m} 2$ in the first year. In the second year it is 25.5 units / $\mathrm{m} 2$ and 96 units / $\mathrm{m} 2$, respectively.

The soil herbicide preparation Merlin Flex 480SK destroys both many of the cereal weed species and some of the annual deciduous weeds. It also controls the jonson grass of seeds and rhizomes, whose leaves turn white and die due to the action of isoxaflutole. The foliar herbicide preparation Aminopielik is highly effective against annual and perennial weed species.

Under the experimental conditions, the herbicide system Spectrum + Lumax destroys $80.2 \%$ of weed species in the first year of the study, and in the second year the percentage is lower $-77.1 \%$. This is due to both the higher number of weeds in the zero control in 2018 and the differences in climate in the two years. In total, during both years of testing, the treatment with the soil herbicide Spectrum at a dose of $140 \mathrm{ml} / \mathrm{dca}$ and the leaf Lumax at a dose of $300 \mathrm{ml} /$ dca showed excellent action against the following types of weeds: white quince, spread quince, common quince and field mustard.

Treatment with the soil herbicide Gardoprim plus gold at a dose of $450 \mathrm{ml} / \mathrm{dka}$ and subsequent leaf Maton at a dose of $110 \mathrm{ml}$ / dka leads to the death of $79.7 \%$ of weed species in the experimental area. The foliar herbicide Maton has a pronounced effect against annual deciduous species - white quince, common and spreading sage, field mustard and others. When considering the nondead weed species in the experimental area, no density of the above species was found. The effect of the herbicide preparation Maton against the types of purslane, black dog grapes, periwinkle, bonito and jonson grass is less pronounced.

Treatment with the herbicide combination Dual Gold 960EK at a dose of $150 \mathrm{ml} / \mathrm{dca}+$ Elumis at a dose of $200 \mathrm{ml} / \mathrm{dca}$ destroys $96.6 \%$ of the available weed species in the experimental area (2017). The two herbicides studied have a broad spectrum of action against the main annual and perennial species, including jonson grass. In the variant in which the two herbicides were imported, only single species of black dog grapes, bonito and jonson grass were reported. In 2018, the same herbicide system destroyed $94.8 \%$ of the weeds in the experimental area.

The results for the biological efficacy of the soil and foliar herbicide systems reported on the 40th day after treatment are as follows:

Under the conditions of 2017, the highest biological efficiency is shown by the system of the soil herbicide preparation Dual Gold in a dose of $150 \mathrm{ml} / \mathrm{dca}$ and the leafy Elumis in a dose of $200 \mathrm{ml} / \mathrm{dca} .90 .3 \%$ of the total number of weeds compared to the zero control were destroyed.

The efficiency of the other systems is lower and varies from $77 \%$ to $80.5 \%$ (Table 3 ).

In 2018, the highest biological efficiency, reported on the 40th day after treatment with foliar herbicides, showed the system of the soil herbicide Adengo 465SK at a dose of $35 \mathrm{ml} / \mathrm{dca}$ and foliar Elumis at a dose of $200 \mathrm{ml} / \mathrm{dca}$ (table 4).

It is noteworthy that in both years of the study the highest biological efficiency was found in the herbicide systems, which included the foliar preparation Elumis in a dose of 200 $\mathrm{ml} / \mathrm{dca}$. This is due to the broad spectrum of action of the herbicide against annual cereals and deciduous weeds, as well as against seed jonson grass.

The biological efficacy of the other herbicide systems reported on day 40 after 
Table1. Biological efficacy of herbicide systems in maize, 20 days after treatment with foliar preparations, 2017

\begin{tabular}{|c|c|c|c|c|c|c|c|c|c|c|c|}
\hline \multirow{2}{*}{ Variants } & \multicolumn{7}{|c|}{ Annual species of weeds } & \multicolumn{2}{|c|}{$\begin{array}{c}\text { Perennial weed } \\
\text { species }\end{array}$} & \multirow{2}{*}{$\begin{array}{c}\text { Total } \\
\text { number }\end{array}$} & \multirow{2}{*}{$\begin{array}{c}\% \\
\text { destroyed } \\
\text { weeds }\end{array}$} \\
\hline & $\begin{array}{l}\text { Ch. } \\
\text { album }\end{array}$ & \begin{tabular}{|c|} 
A. \\
blitoides
\end{tabular} & $\begin{array}{c}\text { A. } \\
\text { retroflexus }\end{array}$ & $\begin{array}{c}\mathrm{S} . \\
\text { arvensis }\end{array}$ & $\begin{array}{c}\mathrm{P} . \\
\text { oleracea }\end{array}$ & $\begin{array}{c}\text { S. } \\
\text { nigrum }\end{array}$ & $\begin{array}{c}\mathrm{S} . \\
\text { viridis }\end{array}$ & $\begin{array}{c}\text { C. } \\
\text { arvense }\end{array}$ & $\begin{array}{c}\text { S. } \\
\text { halepense }\end{array}$ & & \\
\hline $\begin{array}{l}\text { 1. Adengo } 465 \mathrm{SC}-35 \mathrm{ml} / \mathrm{da} \\
+ \text { Elumis }-200 \mathrm{ml} / \mathrm{da}\end{array}$ & - & - & - & - & 2,0 & 1,0 & 1,0 & 1,0 & 2,0 & 7,0 & $93,2++$ \\
\hline $\begin{array}{l}\text { 2. Merlin flex }-42 \mathrm{ml} / \mathrm{da}+ \\
\text { Aminopielic }-120 \mathrm{ml} / \mathrm{da}\end{array}$ & - & 2,0 & 3,0 & - & 2,0 & 1,0 & 2,0 & 5,0 & 10,0 & 25,0 & $71,8++$ \\
\hline $\begin{array}{l}\text { 3. Spectrum }-140 \mathrm{ml} / \mathrm{da}+ \\
\text { Lumax }-300 \mathrm{ml} / \mathrm{da}\end{array}$ & - & - & - & - & 1,0 & 2,0 & 1,5 & 5,0 & 8,0 & 17,5 & $80,2++$ \\
\hline $\begin{array}{l}\text { 4. Gardoprim plus gold }-450 \\
\mathrm{ml} / \mathrm{da}+\text { Maton }-110 \mathrm{ml} / \mathrm{da}\end{array}$ & - & - & - & - & - & 2,0 & 2,0 & 4,0 & 10,0 & 18,0 & $79,7++$ \\
\hline $\begin{array}{l}\text { 5. Dual gold } 960 \mathrm{EK}-150 \\
\mathrm{ml} / \mathrm{da}+\text { Elumis }-200 \mathrm{ml} / \mathrm{da}\end{array}$ & - & - & - & - & - & 1,0 & - & 1,0 & 1,0 & 3,0 & $96,6++$ \\
\hline 6. Zero control & 13,0 & 12,5 & 14,0 & 10,0 & 9,0 & 6,0 & 8,0 & 5,0 & 11,0 & 88,5 & - \\
\hline $\begin{array}{l}\text { 7. Economic control - with } \\
\text { hoeing }\end{array}$ & 2,0 & 2,0 & 1,0 & - & 2,0 & 2,0 & 8,0 & 1,0 & 1,0 & 19,0 & $84,2++$ \\
\hline
\end{tabular}

Proof of the differences in variants compared to the zero control:

$$
\begin{aligned}
& \mathrm{GD}_{\mathrm{p}=5 \%}(+)=6,45 \\
& \mathrm{GD}_{\mathrm{p}=1 \%}(++)=9,85 \\
& \mathrm{GD}_{\mathrm{p}=0.1 \%}(+++)=12,3
\end{aligned}
$$


Table 2. Biological efficacy of herbicide systems in maize, 20 days after treatment with foliar preparations, 2018

\begin{tabular}{|c|c|c|c|c|c|c|c|c|c|c|c|}
\hline \multirow{2}{*}{ Variants } & \multicolumn{7}{|c|}{ Annual species of weeds } & \multicolumn{2}{|c|}{$\begin{array}{l}\text { Perennial weed } \\
\text { species }\end{array}$} & \multirow{2}{*}{$\begin{array}{c}\text { Total } \\
\text { number }\end{array}$} & \multirow{2}{*}{$\begin{array}{c}\% \text { destroyed } \\
\text { weeds }\end{array}$} \\
\hline & $\begin{array}{l}\text { Ch. } \\
\text { album }\end{array}$ & \begin{tabular}{|c|} 
A. \\
blitoides
\end{tabular} & $\begin{array}{c}\text { A. } \\
\text { retroflexus }\end{array}$ & $\begin{array}{c}\mathrm{S} . \\
\text { arvensis }\end{array}$ & $\begin{array}{c}\mathrm{P} . \\
\text { oleracea }\end{array}$ & $\begin{array}{c}\text { S. } \\
\text { nigrum }\end{array}$ & $\begin{array}{c}\text { S. } \\
\text { viridis }\end{array}$ & \begin{tabular}{|c|}
$\mathrm{C}$. \\
arvense
\end{tabular} & $\begin{array}{c}\text { S. } \\
\text { halepense }\end{array}$ & & \\
\hline $\begin{array}{l}\text { 1. Adengo } 465 \mathrm{SC}-35 \\
\mathrm{ml} / \mathrm{da}+\text { Elumis }-200 \mathrm{ml} / \mathrm{da}\end{array}$ & - & - & 1 & - & 4 & 2 & 3 & 2 & - & 12 & 87,5 \\
\hline $\begin{array}{l}\text { 2. Merlin flex }-42 \mathrm{ml} / \mathrm{da}+ \\
\text { Aminopielic }-120 \mathrm{ml} / \mathrm{da}\end{array}$ & 1 & 1 & 2 & - & 3 & 1,5 & 1 & 7 & 9 & 25,5 & 73,4 \\
\hline $\begin{array}{l}\text { 3. Spectrum }-140 \mathrm{ml} / \mathrm{da}+ \\
\text { Lumax }-300 \mathrm{ml} / \mathrm{da}\end{array}$ & 1 & - & - & - & 1,5 & 3,5 & 1,0 & 8,0 & 7,0 & 22 & 77,1 \\
\hline $\begin{array}{l}\text { 4. Gardoprim plus gold }-450 \\
\mathrm{ml} / \mathrm{da}+\text { Maton }-110 \mathrm{ml} / \mathrm{da}\end{array}$ & - & - & - & - & - & 4 & 2 & 6,5 & 8,5 & 21 & 78,1 \\
\hline $\begin{array}{l}\text { 5. Dual gold 960EK }-150 \\
\mathrm{ml} / \mathrm{da}+\text { Elumis }-200 \mathrm{ml} / \mathrm{da}\end{array}$ & - & - & - & - & 1 & 2 & - & 2 & - & 5 & 94,8 \\
\hline 6. Zero control & 15 & 14 & 13,5 & 12 & 11 & 8 & 6 & 7,5 & 9 & 96 & - \\
\hline $\begin{array}{l}\text { 7. Economic control - with } \\
\text { hoeing }\end{array}$ & 1 & 1 & 2,5 & - & 2 & - & 2 & - & 4 & 12,5 & 87 \\
\hline
\end{tabular}

Proof of the differences in variants compared to the zero control:

$$
\begin{aligned}
& \mathrm{GD}_{5 \%}=5,2 \\
& \mathrm{GD}_{1 \%}=7,5 \\
& \mathrm{GD}_{0,1 \%}=10,8
\end{aligned}
$$


Table 3. Biological efficacy of herbicide systems in maize, 40 days after treatment with foliar preparations, 2017

\begin{tabular}{|c|c|c|c|c|c|c|c|c|c|c|c|}
\hline \multirow{2}{*}{ Variants } & \multicolumn{7}{|c|}{ Annual species of weeds } & \multicolumn{2}{|c|}{$\begin{array}{c}\text { Perennial weed } \\
\text { species }\end{array}$} & \multirow{2}{*}{$\begin{array}{c}\text { Total } \\
\text { number }\end{array}$} & \multirow{2}{*}{$\begin{array}{c}\% \\
\text { destroyed } \\
\text { weeds }\end{array}$} \\
\hline & $\begin{array}{l}\text { Ch. } \\
\text { album }\end{array}$ & $\begin{array}{c}\text { A. } \\
\text { blitoides }\end{array}$ & $\begin{array}{c}\text { A. } \\
\text { retroflexus }\end{array}$ & $\begin{array}{c}\mathrm{S} . \\
\text { arvensis }\end{array}$ & $\begin{array}{c}\mathrm{P} . \\
\text { oleracea }\end{array}$ & $\begin{array}{c}\text { S. } \\
\text { nigrum }\end{array}$ & $\begin{array}{l}\mathrm{S} . \\
\text { viridis }\end{array}$ & $\begin{array}{c}\text { C. } \\
\text { arvense }\end{array}$ & $\begin{array}{c}\text { S. } \\
\text { halepense }\end{array}$ & & \\
\hline $\begin{array}{l}\text { 1. Adengo } 465 \mathrm{SC}-35 \\
\mathrm{ml} / \mathrm{da}+\text { Elumis }-200 \mathrm{ml} / \mathrm{da}\end{array}$ & 2 & 3 & 2 & 1 & 4 & 2 & 2 & 3 & 5 & 24 & $78,6++$ \\
\hline $\begin{array}{l}\text { 2. Merlin flex }-42 \mathrm{ml} / \mathrm{da}+ \\
\text { Aminopielic }-120 \mathrm{ml} / \mathrm{da}\end{array}$ & - & 1 & 1 & - & 1 & 1 & 1 & 6 & 15 & 26 & $77,0++$ \\
\hline $\begin{array}{l}\text { 3. Spectrum }-140 \mathrm{ml} / \mathrm{da}+ \\
\text { Lumax }-300 \mathrm{ml} / \mathrm{da}\end{array}$ & - & - & - & - & 1 & 3 & 1 & 7 & 10 & 22 & $80,5++$ \\
\hline $\begin{array}{l}\text { 4. Gardoprim plus gold }-450 \\
\mathrm{ml} / \mathrm{da}+\text { Maton }-110 \mathrm{ml} / \mathrm{da}\end{array}$ & 1 & 1 & 1 & 2 & 1 & 1 & 3 & 6 & 8 & 24 & $78,8++$ \\
\hline $\begin{array}{l}\text { 5. Dual gold } 960 \mathrm{EK}-150 \\
\mathrm{ml} / \mathrm{da}+\text { Elumis }-200 \mathrm{ml} / \mathrm{da}\end{array}$ & - & 1 & 1 & - & 1 & 2 & 1 & 3 & 2 & 11 & $90,3+++$ \\
\hline 6. Zero control & 15 & 14 & 16 & 15 & 10 & 8 & 10 & 10 & 15 & 113 & - \\
\hline $\begin{array}{l}\text { 7. Economic control - with } \\
\text { hoeing }\end{array}$ & 5 & 3 & 3 & 1 & 3 & 5 & 10 & 2 & 3 & 35 & $82,0++$ \\
\hline
\end{tabular}

Proof of the differences in variants compared to the zero control:

$$
\begin{aligned}
& \operatorname{gDp}_{5 \%}=6,3 \\
& \operatorname{gDp}_{1 \%}=8,2 \\
& \operatorname{gDp}_{0,1 \%}=11,3
\end{aligned}
$$


Table 4. Biological efficacy of herbicide systems in maize, 40 days after treatment with foliar preparations, 2018

\begin{tabular}{|c|c|c|c|c|c|c|c|c|c|c|c|}
\hline \multirow{2}{*}{ Variants } & \multicolumn{7}{|c|}{ Annual species of weeds } & \multicolumn{2}{|c|}{$\begin{array}{c}\text { Perennial weed } \\
\text { species }\end{array}$} & \multirow{2}{*}{$\begin{array}{c}\text { Total } \\
\text { number }\end{array}$} & \multirow{2}{*}{$\begin{array}{c}\% \\
\text { destroyed } \\
\text { weeds }\end{array}$} \\
\hline & $\begin{array}{c}\text { Ch. } \\
\text { album }\end{array}$ & $\begin{array}{c}\text { A. } \\
\text { blitoides }\end{array}$ & \begin{tabular}{c|} 
A. \\
retroflexus
\end{tabular} & $\begin{array}{c}\mathrm{S} . \\
\text { arvensis }\end{array}$ & $\begin{array}{c}\mathrm{P} . \\
\text { oleracea }\end{array}$ & $\begin{array}{c}\mathrm{S} . \\
\text { nigrum }\end{array}$ & $\begin{array}{c}\text { S. } \\
\text { viridis }\end{array}$ & $\begin{array}{c}\mathrm{C} . \\
\text { arvense }\end{array}$ & $\begin{array}{c}\text { S. } \\
\text { halepense }\end{array}$ & & \\
\hline $\begin{array}{l}\text { 1. Adengo } 465 \mathrm{SC}-35 \\
\mathrm{ml} / \mathrm{da}+\text { Elumis }-200 \mathrm{ml} / \mathrm{da}\end{array}$ & 1 & 1 & 3 & - & 6 & 3 & 5 & 5 & 2 & 26 & $75,7+++$ \\
\hline $\begin{array}{l}\text { 2. Merlin flex }-42 \mathrm{ml} / \mathrm{da}+ \\
\text { Aminopielic }-120 \mathrm{ml} / \mathrm{da}\end{array}$ & 2 & 3 & 3 & 1 & 4 & 3 & 2 & 9 & 15 & 42 & $60,8+++$ \\
\hline $\begin{array}{l}\text { 3. Spectrum }-140 \mathrm{ml} / \mathrm{da}+ \\
\text { Lumax }-300 \mathrm{ml} / \mathrm{da}\end{array}$ & 1 & 1 & 2 & 2 & 4 & 5 & 2 & 10 & 11 & 38 & $64,5+++$ \\
\hline $\begin{array}{l}\text { 4. Gardoprim plus gold }-450 \\
\mathrm{ml} / \mathrm{da}+\text { Maton }-110 \mathrm{ml} / \mathrm{da}\end{array}$ & 1 & 1 & 2 & 1 & 2 & 5 & 4 & 5 & 9 & 30 & $27,0+++$ \\
\hline $\begin{array}{l}\text { 5. Dual gold 960EK }-150 \\
\mathrm{ml} / \mathrm{da}+\text { Elumis }-200 \mathrm{ml} / \mathrm{da}\end{array}$ & - & - & - & - & 1 & 1 & - & 3 & 1 & 6 & $72,0+++$ \\
\hline 6. Zero control & 20 & 15 & 15 & 10 & 12 & 9 & 8 & 8 & 10 & 107 & - \\
\hline $\begin{array}{l}\text { 7. Economic control - with } \\
\text { hoeing }\end{array}$ & 1 & 2 & 1 & 1 & 1 & 1 & 3 & 2 & 5 & 17 & $84,1+++$ \\
\hline
\end{tabular}

Proof of the differences in variants compared to the zero control:

$$
\begin{aligned}
& \mathrm{gDp}_{5 \%}=20,2 \\
& \operatorname{gDp}_{1 \%}=21,3 \\
& \mathrm{gDp}_{0,1 \%}=10,8
\end{aligned}
$$


75 years of Agricultural University - Plovdiv

JUBILEE SCIENTIFIC INTERNATIONAL

CONFERENCE Plovdiv 26-28 November 2020
PERSPECTIVES ON AGRICULTURAL SCIENCE

AND INNOVATIONS FOR SUSTAINABLE

FOOD SYSTEMS treatment was lower due to the limited range of action of the foliar herbicides.

\section{CONCLUSIONS}

The species composition of weeds in the experimental area of the Maize Research Institute - Knezha during the years of the experiment (2017 and 2018) includes the following weed species: white quince, spreading sagebrush, common sagebrush, mustard, purslane, black dog grapes, hindsight, bonito and jonson grass (from seeds and rhizomes).

Under the conditions of the experiment, the herbicidal system Dual Gold 960EK at a dose of $150 \mathrm{ml} / \mathrm{dca}+$ Elumis at a dose of 200 $\mathrm{ml} / \mathrm{dca}$ is the most efficient of the studied systems, destroying $96.6 \%$ and $94.8 \%$ of the common weed species in the experimental area in the years of conducting the experiment.

In total, over the years of study, the biological efficacy of herbicide systems ranged from $71.8 \%$ to $96.6 \%$.

\section{REFERENCES}

Bagrinzeva, V. N. et. al., 2011. Effectivnost primenenia gerbicidov на kukuruze. Kukuruza I sorgo, № 1, 24-30.

Changsaluk, S. et. al., 2007. Effect of weed densities of fresh corn yield. In proceedings of the $45^{\text {th }}$ Kasetsart University, Annual Conference, Bangok, Thailand, 30 Fanuary - 2 February, on CD.

Dimitrova, M. et al., 2004. Methodology for reporting and filing of weed infestation in major field crops. Sofia, National Service for Plant Protection at MAF (Bg).

Golubinova, I., P. Marinov-Serafimov, 2019. Vlianie na lactisem vurchu kalniaemostta u parvonachalnoto razvitie na obrazci Sorghum vulgare var. technicum (Körn). Journal of Mountain Agriculture on the Balkans, vol. 22, № 6, 176-186.
Jovović, Z. et al., 2011. Efficiency of metolaclor in weed control in potato crop depending on dose and time of application. Herbologia, vol. 12, № 2, 7-15.

Kalinova, St., S. Kostadinova, A. Hristoskov, 2014. Nitrogen Use Efficiency and Maize Yield Response to nitrogen Rate and Foliar Fertilizing Bulgarian Journal of Agriculture Science. 20, № 1, 194197.

Malakanova, V. P. et. al., 2013. Effectivnost chimitheskich mer zachita roditelckich form kukuruza ot sorniakov $\mathrm{v}$ Krasnodarskom krae. Kukuruza I sorgo, № 1, 25-28.

Marić, D., 2007. Testing of efficacy of some herbicides combination in maize. Herbologia, vol. 8, № 1, 177-179.

Mitkov, A., M. Yanev, N. Neshev, T. Tonev, 2018. Biological efficacy of some soil herbicides at maize (Zea mays L.). Scientific Papers. Series A. Agronomy, Vol. LXI, № 1, 340-345.

Mitkov, M. Yanev, N. Neshev, M. Tityanov, T. Tonev, 2019. Herbicide control of the weeds in maize (Zea mays L.). Scientific Papers. Series A. Agronomy, Vol. LXII, № 1, 368-373.

Spitters, C. J. T. et. al., 1989. Competition between maize and Echinochloa crusgalli, analysed by a hyperbolic regression model. Anu Apple. Biol., 115, 541-551.

Tollenaar, M. et al., 1997. Grain yield is reduced more by weed interference in an old than in a new maize hybrid. Agronomical Journal, vol. 89, № 1, 239-246.

Tonev, T., M. Tityanov, A. Mitkov, M. Yanev, N. Neshev, 2016. Control of highly blended weeding at maize (Zea mays L.). Book of Proceedings, VII International Scientific Agriculture Symposium "Agrosym 2016", Jahorina, October $06^{\text {th }}-09^{\text {th }}, 1256-1262$.

Tonev, T., A. Mitkov, 2015. Chimicheska borba srechu plevelite pri osnovnite polski kulturi. Zemedelie plus, 3-4, 21-23. 